\title{
PENERAPAN TEKNOLOGI INFORMASI DAN KOMUNIKASI \\ DI DESA (Studi Kasus di Kabupaten Lamongan)
}

\author{
Yuniadi Mayowan \\ Fakultas Ilmu Administrasi, Universitas Brawijaya Malang \\ Email: ymayowan@ub.ac.id
}

\begin{abstract}
Information and Communication Technology (ICT) development more and more fast especially in streamlining public service and must reach village level. Beside increasing sercive, ICT has benefit in data processing that is able to be used in development planning, supporting in decision making and others. The goal of this study is to identify the readyness of ICT implementation of human resource, facilities and infrastructure, institutional and budgetting aspects and IT service in village level. Descriptive methode is used and location take place in four villages in Lamongan Regency. Finding is showed the limit number of human resurce who has ICT capability, undistributed of internet network, fulfilled of institutional needs and budgetting support from authorized institution. Finally, information system does not have all service program to serve public and still does not implement in all village government in servicing public.
\end{abstract}

Keyword: ICT, readyness on ICT implementation, IT service

\begin{abstract}
ABSTRAK
Perkembangan teknologi informasi dan komunikasi (TIK) yang semakin pesat dalam usaha mengefektifkan layanan kepada masyarakat harus dilakukan sampai pada tingkat Desa. Keberadaan TIK selain dapat meningkatkan pelayanan juga bermanfaat dalam proses pengolahan data yang dapat digunakan untuk perencanaan pembangunan, mendukung pengambilan keputusan dan banyak manfaat lainnya. tujuan kajian ini adalah untuk mengidentifikasi kesiapan penerapan TIK dilihat dari aspek sumberdaya manusia, sarana dan prasarana, kelembagaan dan anggaran dan menilai pelayanan melalui IT yang telah di lakukan. Metode yang digunakan adalah metode deskriptif dengan lokasi penelitian di 4 desa di Kabupaten Lamongan. Hasil temuan penelitian adalah keterbatasan jumlah SDM yang menguasai TIK, belum meratanya jaringan, tercukupinya kebutuhan kelembagaan dan adanya dukungan anggaran dari lembaga yang berwenang dan sistem informasi belum mengakomodir semua kebutuhan layanan dan belum diterapkan di semua desa.
\end{abstract}

\section{Kata kunci: TIK, Kesiapan penerapan TIK, Pelayanan IT}




\section{A. PENDAHULUAN}

Sistem informasi merupakan perpaduan antara teknologi informasi dan aktivitas orang. Teknologi informasi yang tercanggih sekalipun tetapi tidak ada yang mengoperasikan mengakibatkan sistem informasi tidak berjalan maksimal. Perpaduan teknologi informasi dan manusia pengelola merupakan kunci suksesnya penerapan sistem informasi. Pekerjaan yang berulang-ulang dapat digantikan oleh sistem untuk menyederhanakan pekerjaan. Berjalannya peran sistem informasi menyebabkan kinerja organisasi menjadi semakin efisien dan efektif.

Menurut UU nomor 6 tahun 2014 tentang Desa, Pembangunan Desa adalah upaya peningkatan kualitas hidup dan kehidupan untuk sebesar-besarnya kesejahteraan masyarakat desa. Lebih lanjut UU tersebut juga menjelaskan bahwa, pembangunan desa dalam hal ini, mencakup empat bidang pembangunan yaitu penyelenggaraan pemerintahan desa, pelaksanaan pembangunan desa, pembinaan kemasyarakatan desa dan pemberdayaan masyarakat desa. Pembangunan desa yang difokuskan pada keempat lingkup pembangunan tersebut hendak menegaskan esensi dari UU desa yakni memberikan kewenangan yang lebih besar kepada desa untuk tidak hanya dijadikan objek pembangunan tetapi lebih mandiri menjadi objek sekaligus subjek pembangunan.

Pembangunan desa tersebut dapat ditopang oleh sistem informasi dan konsep eGovernment menjadi pertimbangan utama bagi organisasi sektor publik (pemerintah desa) yang melakukan perencanaan sistem informasi dalam rangka menyediakan input penting dan memudahkan dalam proses penyusunan perencanaan dan pemantauan dan evaluasi hasil pembangunan. Teknologi Informasi dan Komunikasi (TIK) menjadi bagian dari gugusan pembuat layanan dari pemerintah dan semakin besar pengaruhnya pada organisasi, profesional yang bekerja di dalamnya, serta hubungannya dengan publik. Semua rencana kebijakan untuk e-Goverment telah fokus pada isu-isu operasional internal, pemberian layanan jasa pemerintah dan teknologi itu sendiri yang secara masif dipercayakan pada TIK sebagai instrumen untuk menjadikan pemerintah lebih efektif, lebih bersahabat dan mudah dihubungi bagi masyarakat yang harus dilayani. Demikian halnya, semakin besar pula pengaruhnya bagi pembuat kebijakan dan politisi yang menggunakan TIK untuk menyelesaikan masalah pekerjaan administratif yang komplek dan menangani kasus-kasus yang menonjol seperti perencanaan pembangunan, mobilitas, pembagian barang serta pelayanan publik yang tertunjang.

TIK dapat menjadi alat untuk memperbaiki administrasi desa. Administrasi desa seperti kita ketahui bersama mempunyai banyak kelemahan diantaranya adalah proses update dimana data yang ada di tingkat desa berbeda dengan data yang ada di tingkat kecamatan karena perbedaan memutakhirkan data di tingkat desa dan kecamatan, begitu juga dengan tingkat kabupaten.

Dukungan TIK yang diterapkan pada pemerintah desa akan mendorong data tunggal yang dengan mudah diupdate oleh aparatur desa dengan mengedepankan kesederhanaan operasional sehingga terjadi satu kesatuan data baik di tingkat desa, kecamatan dan kabupaten. Sistem informasi desa juga diatur dalam UU No. 6 tahun 2014 tentang desa di bagian ketiga Sistem Informasi Pembangunan Desa dan Pembangunan Kawasan Perdesaan Pasal 86. Isinya antara lain bahwa Sistem informasi Desa meliputi fasilitas perangkat keras dan perangkat lunak, jaringan, serta sumber daya manusia. Sistem informasi tersebut meliputi data Desa, data Pembangunan Desa, Kawasan Perdesaan, serta informasi lain yang berkaitan dengan Pembangunan Desa dan pembangunan Kawasan Perdesaan, dikelola oleh pemerintah dan dapat diakses oleh masyarakat Desa dan semua pemangku kepentingan. Sistem informasi tersebut diisyaratkan untuk menyediakan informasi perencanaan pembangunan Kabupaten/Kota untuk Desa.

Pada pelaksanaannnya tidak lupa akan pentingnya proses pendampingan untuk memampukan aparatur dalam mengelola TIK. Data yang tersimpan dengan baik sangat mendukung kinerja pemerintah desa sesuai azas efisien dan efektif, pembakuan, akuntabilitas, keterkaitan, kecepatan dan ketepatan, keamanan, ketelitian, kejelasan, singkat dan padat dan logis dan meyakinkan dalam rangka penyusunan perencanaan desa, perbaikan administrasi desa dan pelayanan publik. Sarana prasarana TIK harus siap baik dari sisi software dan hardware, kelembagaan dan anggaran yang memadai sangat diperlukan agar pelayanan IT dapat dilaksanakan dengan baik. 
Tujuan kajian ini adalah untuk melihat kesiapan penerapan TIK dilihat dari aspek sumber daya manusia, sarana prasarana, kelembagaan dan anggaran, dan pelayanan IT yang dilakukan oleh Pemerintah Desa.

Metode yang digunakan adalah metode deskriptif yang mengambil lokasi kajian di Desa Putatkumpul, Desa Balun, Desa Babatkumpul dan Desa Padenganploso Kabupaten Lamongan. Data dikumpulkan melalui wawancara, observasi dan dokumentasi. Data yang diperoleh dianalisis menggunakan a nine steps process for analyzing qualitatve data (McNabb, 2010).

\section{B. LATAR BELAKNG TEORI DAN HIPOTESIS \\ 1. Pelayanan Pemerintahan Desa}

Pengaturan tata kelola desa yang terbaru mengikuti Undang-Undang no. 6 tahun 2014 tentang desa. Pengaturan Desa dalam undangundang ini bertujuan untuk memberikan pengakuan dan penghormatan atas Desa yang sudah ada dengan keberagamannya sebelum dan sesudah terbentuknya Negara Kesatuan Republik Indonesia; memberikan kejelasan status dan kepastian hukum atas Desa dalam sistem ketatanegaraan Republik Indonesia demi mewujudkan keadilan bagi seluruh rakyat Indonesia; melestarikan dan memajukan adat, tradisi, dan budaya masyarakat Desa; mendorong prakarsa, gerakan, dan partisipasi masyarakat Desa untuk pengembangan potensi dan Aset Desa guna kesejahteraan bersama; membentuk Pemerintahan Desa yang profesional, efisien dan efektif, terbuka, serta bertanggung jawab; meningkatkan pelayanan publik bagi warga masyarakat Desa guna mempercepat perwujudan kesejahteraan umum; meningkatkan ketahanan sosial budaya masyarakat Desa guna mewujudkan masyarakat Desa yang mampu memelihara kesatuan sosial sebagai bagian dari ketahanan nasional; memajukan perekonomian masyarakat Desa serta mengatasi kesenjangan pembangunan nasional; dan memperkuat masyarakat Desa sebagai subjek pembangunan.

Dalam pembangunan nasional, desa memegang peranan yang sangat penting, sebab desa merupakan struktur pemerintahan terendah dari sistem pemerintahan Indonesia. Setiap jenis kebijakan pembangunan nasional pasti bermuara pada pembangunan desa sebab pembangunan Indonesia tidak akan ada artinya tanpa membangun desa, dan bisa dikatakan bahwa hari depan Indosesia terletak dan tergantung dari berhasilnya kita membangun desa. Sehingga dengan semangat desentralisasi dalam otonomi daerah ini masyarakat haruslah dilibatkan atau diberdayakan dalam pembangunan desanya. Sebab disadari atau tidak bahwa pembangunan desa telah banyak dilakukan sejak dari dahulu hingga sekarang, tetapi secara umum hasilnya belum memuaskan terhadap peningkatan kesejahteraan masyarakat pedesaan.

Sebagai miniatur negara Indonesia, Desa menjadi arena politik paling dekat bagi relasi antara masyarakat dengan pemegang kekuasaan (perangkat Desa). Di satu sisi, para perangkat Desa menjadi bagian dari birokrasi negara yang mempunyai daftar tugas kenegaraan, yakni menjalankan birokratisasi di level Desa, melaksanakan program-program pembangunan, memberikan pelayanan administratif kepada masyarakat. Tugas penting pemerintah Desa adalah memberi pelayanan administratif (surat-menyurat) kepada warga. (Depdagri, 2007:27)

Jenis-jenis pelayanan publik yang dilakukan Pemerintah Desa terdiri dari pelayanan dalam bidang administrasi kependudukan, pelayanan administratif, pelayanan kebersihan dan pelayanan pemberian fasilitas pemakaman. Sedangkan menurut Peraturan Menteri Dalam Negeri Nomor 62 Tahun 2008 terdiri dari 1) Pelayanan Dokumen Kependudukan yang mencakup penerbitan Kartu Tanda Penduduk (KTP) dan penerbitan akta kelahiran, 2) Pemeliharaan Ketentraman dan Ketertiban Masyarakat yang mencakup petugas Perlindungan Masyarakat (Linmas) di Kabupaten/Kota dan Tingkat penyelesaian pelanggaran K3 (ketertiban, ketentraman, keindahan) di Kabupaten/Kota, dan 3) Penanggulangan Bencana Kebakaran yang mencakup pelayanan bencana kebakaran kabupaten/kota dan Tingkat waktu tanggap (response time rate) daerah layanan Wilayah Manajemen Kebakaran (WMK).

Administrasi Desa adalah keseluruhan proses kegiatan pencatatan data dan informasi mengenai penyelenggaraan Pemerintahan Desa pada Buku Administrasi Desa. Beberapa macam kegiatan administrasi pemerintahan di desa atau kelurahan yang wajib dilaksanakan dengan tertib, terdiri atas Administrasi Umum, Administrasi Penduduk, Administrasi Keuangan, Administrasi Pembangunan dan Administrasi Badan Permusyawaratan Desa. 


\section{Masalah Pelayanan Publik Pemerintahan Desa}

Secara umum kita telah mengetahui masalah-masalah yang dihadapi dikelurahan, baik yang bersumber secara internal maupun yang eksternal, seperti semakin pesatnya kegiatan pembangunan yang hasil-hasilnya telah kita rasakan saat ini, namun demikian masih dapat ditemukan pula dampak yang dapat menimbulkan masalah yang baru. Untuk mengatasi masalah tersebut, maka diperlukan kemampuan dibidang perencanaan pembangunan dan pemberian pelayanan yang baik dan berkualitas oleh para aparatur desa/kelurahan kepada masyarakat sehingga permasalahan yang kompleks dan rumit dapat diatasi.

Adapun permasalahan-permasalahan yang dihadapi Aparat Birokrasi Desa dalam mengoptimalkan kegiatan Pemerintahan Desa meliputi permasalahan internal yang berupa ketatalaksanaan, sumber daya manusia atau kompetensi Aparat Pemerintah Desa, ketatalaksanaan, penggunaan teknologi administrasi yang masih kurang, dan manajemen birokrasi itu sendiri. Sedangkan masalah eksternal berupa dinamika masyarakat dan tumbuh kembangnya masalah yang dihadapi masyarakat.(Lulita, 2011)

Selain itu pelayanan yang diberikan oleh pemerintah selama ini masih memiliki beberapa kelemahan yakni kurang responsif; kurang informatif; kurang accessible; kurang koordinasi; birokratis; kurang mau mendengar keluhan/saran/aspirasi masyarakat dan inefisien.

\section{E-Governenment dalam Pelayanan Publik}

Di antara banyak harapan dari revolusi Informasi Komunikasi Teknologi (ICT) adalah potensi untuk memodernisasi organisasi pemerintah, memperkuat operasi mereka dan membuat mereka lebih responsif terhadap kebutuhan warganya. Banyak negara telah memperkenalkan program e-Government berbasis TIK dan menggunakannya untuk mengubah dimensi beberapa operasi pemerintahan, untuk menciptakan pemerintahan yang lebih mudah diakses, transparan, efektif, dan akuntabel. (Al-Khouri, 2011:1)

Dalam beberapa tahun terakhir, pengembangan e-Government telah mendapatkan momentum yang signifikan meskipun terjadi krisis keuangan yang melumpuhkan ekonomi dunia. Bagi sebagian besar pemerintah, krisis keuangan baru-baru ini memicu kebangkitan untuk menjadi lebih transparan dan efisien. Selain itu, ada juga permintaan terhadap pemerintah untuk mengubah dari agen tradisional dan model departemen sentris menjadi model "CitizenCentric". Transformasi tersebut diharapkan dapat meningkatkan kualitas hidup warga dalam hal kenyamanan yang lebih besar dalam ketersediaan layanan pemerintah dan dengan demikian menghasilkan tingkat kepuasan pelanggan meningkat dan kepercayaan dalam pemerintahan. (Al-Khouri, 2011:1)

Instansi Pemerintah semakin merangkul Teknologi Informasi dan Komunikasi (TIK) untuk meningkatkan efisiensi dan mengintegrasikan karyawan, mitra dan warga negara secara mulus. Di sisi lain, hal ini menjadi semakin sulit untuk mencapai hasil dan memenuhi kebutuhan warga dengan inisiatif $e$ Government yang terfragmentasi. Keadaan seperti ini memaksa banyak pemerintah untuk mengambil pendekatan terpadu untuk meningkatkan efektivitas memberikan layanan kepada warganya. Setelah secara seksama mempelajari banyak e-program pemerintah terkemuka di seluruh dunia, beberapa di antaranya telah membentuk dedikasi e-instansi pemerintah untuk memberikan transformasi yang diinginkan, kita melihat bahwa sangat sedikit yang berhasil dalam mencapai hasil yang mereka awalnya berharap untuk menyampaikan. Ini tidak berarti bahwa dunia belum menyaksikan setiap inisiatif $e$ Government yang telah berhasil dalam memberikan yang efektif e-layanan kepada warga. Sebaliknya kita melihat bahwa sebagian besar program e-Government telah otomatis dan digital sehingga beberapa proses yang ada dari pelayanan pemerintah telah berubah. $E$ Government bukan hanya tentang mengaktifkan pelayanan pemerintah yang ada di Internet, akan tetapi lebih pada rekonseptualisasi dari pelayanan yang ditawarkan oleh pemerintah sejalan dengan harapan warga sebagai inti rekonseptualisasi tersebut. (Al-Khouri, 2011:12)

Tujuan dasar adalah pembaharuan, serta aplikasi ICT yang terintegrasi di pemerintahan untuk meningkatkan efisiensi, efektivitas, transparansi, tanggung jawab dan ekonomi dalam pekerjaan pemerintah dan para pegawai pemerintah, untuk meningkatkan kualitas dan 
ketersediaan informasi dan layanan yang diberikan kepada pengguna pegawai pemerintah dan memastikan partisipasi yang lebih aktif warga dalam proses pengambilan keputusan dan menyebarkan demokrasi di masyarakat (e-Government).

\section{HASIL DAN PEMBAHASAN}

\section{Kesiapan Penerapan TIK Pada Administrasi Desa}

Dalam usaha untuk mencapai

keberhasilan e-Government dalam layanan administrasi desa yang berbasis IT, ada beberapa faktor yang menentukan keberhasilannya. Faktor tersebut dalam sistem layanan e-Government menurut pendapat Heeks (2001b: 17-19), Gil-Garciá dan Pardo (2005), dan ADB (2011) diantaranya Sumber Daya Manusia (SDM); Sarana dan Prasarana; Kelembagaan; Anggaran; Pelayanan IT dan Standard Layanan Administrasi Desa/Kelurahan.

\section{a. Sumber Daya Manusia (SDM)}

Kesiapan SDM untuk layanan IT administrasi Desa masih kurang. Ada beberapa hal yang menjadi kendala, diantaranya adalah (a) kemampuan SDM dalam penguasaan IT; (b) belum meratanya SDM yang ahli; dan (c) mutasi pegawai. Kemampuan SDM untuk penguasaan IT di Kabupaten Lamongan dapat dikatakan sudah baik dan memadai. Hal ini ditunjukkan dengan berjalannya implementasi PADE di 3 dari 4 desa yang dijadikan sampel, selain itu 3 desa yang sudah melaksanakan PADE ini sudah menerapkan aplikasi layanan yang lain, yaitu Abinduk. Kekurangan yang ada adalah pemerataan kemampuan aparat, karena operator aplikasi tersebut masih terbatas pada aparat yang telah menerima pelatihan.

Hakekat pelayanan publik adalah pemberian pelayanan prima kepada masyarakat yang merupakan perwujudan kewajiban aparatur pemerintah sebagai abdi masyarakat. (2003). Dengan pendapat ini, harusnya tiap aparat pelayan publik harus mempu menyesuaikan diri dengan kemajuan teknologi untuk memberikan layanan prima pada masyarakat. Adapun permasalahanpermasalahan yang dihadapi Aparat Birokrasi Kelurahan/Desa dalam mengoptimalkan kegiatan Pemerintahan Desa meliputi permasalahan internal yang berupa ketatalaksanaan, sumber daya manusia atau kompetensi Aparat Pemerintah Kelurahan/Desa, ketatalaksanaan, penggunaan teknologi administrasi yang masih kurang, dan manajemen birokrasi itu sendiri. Sedangkan masalah eksternal berupa dinamika masyarakat dan tumbuh kembangnya masalah yang dihadapi masyarakat (Lulita, 2011).

Menurut (lulita, 2011) kelemahankelemahan aparat layanan yaitu: (a) Kurang responsif; (b) Kurang informatif; (c) Kurang accessible; (d) Kurang koordinasi; (e) Birokratis; (f) Kurang mau mendengar keluhan/saran/aspirasi masyarakat; dan (f) Inefisien.

Jadi, SDM masih menjadi kendala dalam penerapan IT di Kabupaten Lamongan Jawa Timur. Padahal seharusnya sesuai dengan teori, dalam usaha untuk memaksimalkan layanan dengan penerapan IT tiap aparat pelayan publik harus mampu menyesuaikan diri dengan kemajuan teknologi. Pernyataan dari teori yang menyebutkan kelemahan-kelemahan dari aparat layanan memang sesuai dengan temuan di lapangan. Untuk mengatasi masalah tersebut, maka diperlukan kemampuan dibidang perencanaan pembangunan dan pemberian pelayanan yang baik dan berkualitas oleh para aparatur desa/kelurahan kepada masyarakat.

\section{b. Sarana dan Prasarana}

Penggunaan sarana dan prasarana IT adalah syarat utama suatu layanan dapat dikatakan berbasis IT atau tidak. Penggunaan sarana yang berbasis IT ini mencakup dari sarana itu sendiri dan sarana penunjang keberlangsungan layanan. Sebaran sarana IT di tiap desa pun berbeda. Kabupaten Lamongan juga merupakan daerah yang telah menerapkan aplikasi PADE untuk layanan pada masyarakat. Dalam menunjang pelaksanaan PADE, sarana IT di tiap desa sudah memadai walaupun masih belum merata. Misalnya saja Desa Babatkumpul yang memiliki 2 komputer edisi baru dan 1 laptop, berbeda dengan keadaan desa Padenganploso yang hanya memiliki 1 komputer lama dan 1 laptop yang juga lama. Di sisi lain, jaringan internet sebagai penunjang juga masih belum masuk di 4 desa yang digunakan sebagai sampel, namun, Pemerintah Kabupaten Lamongan telah berencana untuk memasang jaringan wifi ke semua tempat pusat keramaian di Kabupaten Lamongan.

Tersedianya sarana dan prasarana kerja, peralatan kerja dan pendukung lainnya yang memadai termasuk penyediaan sarana teknologi telekomunikasi dan informatika (telematika). Selain itu, Tempat dan lokasi serta sarana 
pelayanan yang memadai, mudah dijangkau oleh masyarakat, dan dapat memanfaatkan teknologi telekomunikasi dan informatika. (Kepmenpan, 2003)

Sarana dan Prasarana juga menjadi perhatian penting dalam penerapan Standar Pelayanan Minimal dengan penyediaan sarana dan prasarana pelayanan yang memadai oleh penyelenggara pelayanan publik. Berdasarkan Peraturan Pemerintah No. 72 tahun 2005, pada ayat (2) poin "e" menyatakan bahwa terbentuknya suatu desa harus memenuhi syarat Sarana dan Prasarana Pemerintahan.

Sarana dan prasarana adalah suatu sayarat yang harus dipenuhi untuk memberikan layanan sesuai dengan yang Kepmenpan No. 63, th 2003. Sarana teknologi dan pendukungnya merupakan fokus dari pelayanan yang berbasis IT, semakin canggih sarana IT maka semakin bagus layanan yang dapat diberikan pada masyarakat. Sesuai dengan pendapat (Charalabidis et al, 2006) untuk layanan e-publik, teknologi yang dimiliki oleh tiap pemberi layanan harus dapat mencakup semua segi yang telah dijabarkan, dan sayangnya ini masih belum dapat dipenuhi oleh semua desa yang dijadikan sampel. Jadi kesimpulan yang dapat diambil adalah mayoritas desa terkait sarana komputer sudah memadai dan yang perlu menjadi perhatian terkait sarana pendukung adalah jaringan internet yang perlu dipasang merata.

\section{c. Kelembagaan}

Kelembagaan adalah hal yang penting dalam penerapan layanan yang berbasis IT, karena pada aspek kelembagaan menjadi organisasi yang menunjukkkan alur pertanggungjawaban untuk penerapan layanan publik berbasis IT.

Kelembagaan layanan administrasi desa di Kabupaten Lamongan dapat dikatakan sudah baik. Pelaksanaan PADE menjadi tanggungjawab pihak Pemkab Lamongan melalui Bagian Pemerintahan Desa (Pemdes). Pemdes menggandeng KPDE dalam pembuatan, dan pendampingan PADE, karena KPDE adalah instansi pemerintah yang kompeten dalam pengembangan sistem informasi di Kabupaten Lamongan dan sudah sesuai dengan aturan terkait dengan penerapan PADE. Dalam peneraparan PADE ini, pihak Pemkab menggunakan SDM dari Kantor Pengolahan Data Elektronik (KPDE) sebagai tim ahli yang membuat aplikasi dan memberikan pendampingan pada aplikasi ini. Dengan adanya PADE, Pemkab juga memberikan tugas kepada kecamatan untuk mengawal, mengawasi, dan menyambungkan aspirasi dari desa ke Pemkab keberlangsungan program ini. Pihak desa diberikan kewajiban mengirimkan paling tidak 1 orang untuk menerima pelatihan oleh Pemkab dan orang tersebut juga diwajibkan untuk mengajari aparat lain yang ada di desa. Sesuai dengan Peraturan Bupati Lamongan Nomor 34 Tahun 2008, KPDE berkedudukan sebagai unsur pendukung tugas Kepala Daerah yang dipimpin oleh seorang Kepala Kantor berada di bawah dan bertanggungjawab kepada Kepala Daerah melalui Sekretaris Daerah dengan tugas melaksanakan penyusunan dan pelaksanaan kebijakan daerah di bidang pengolahan data elektronik.

Dengan kelembagaan yang baik, akan menciptakan sistem layanan yang baik pula. Sejumlah faktor yang mendorong kepuasan pelanggan atau pengguna jasa di seluruh pelayanan publik dapat diidentifikasi: pengiriman, ketepatan waktu, penyediaan informasi, profesionalisme dan sikap staf.

Aspek kelembagaan juga menjelaskan alur dari pengaduan, karena setiap pimpinan unit penyelenggara pelayanan pelayanan publik wajib menyelesaikan setiap laporan atau pengaduan masyarakat mengenai ketidakpuasan dalam pemberian pelayanan sesuai kewenangannya. Selain itu, pimpinan penyelenggara pelayanan publik wajib secara berkala mengadakan evaluasi terhadap kinerja penyelenggaraan pelayanan di lingkungan secara berkelanjutan dan hasilnya secara berkala dilaporkan kepada pimpinan tertinggi penyelenggara pelayanan publik. Dalam melakukan evaluasi kinerja pelayanan publik harus menggunakan indikator yang jelas dan terukur sesuai ketentuan yang berlaku (Kepmenpan No. 63, 2003).

Kesimpulan yang dapat diambil dari data yang disesuaikan dengan teori yang ada, maka Kabupaten Lamongan memenuhi kebutuhan akan kelembagaan dengan ditanganinya IT oleh Kantor Pengelolaan Data Elektronik (KPDE) yang diberikan wewenang untuk mengurus pengembangan layanan desa yang berbasis IT dan mengembangkannya sampai ke Desa.

\section{d. Anggaran}

Alokasi anggaran untuk layanan pada masyarakat khususnya yang terkait untuk 
layanan berbasis IT akan menunjukkan keseriusan dari pemegang otoritas untuk penerapan E-Government. Urusan penganggaran merupakan urusan yang sangat penting, karena dibutuhkan pertanggungjawaban yang serius. Daerah yang menerapkan layanan aplikasi, dalam penerapannya menggunakan dana Anggaran Penerimaan dan Belanja Daerah (APBD) Kabupaten/Kota. Kabupaten Lamongan dalam pengadaan PADE sesuai dengan keputusan Bupati Lamongan No. 188/324/Kep/413.013/2013 tentang Penunjukan Desa Percontohan Pelaksanaan Program Pengolahan Administrasi Desa Secara Elektronik (PADE), membuat pengadaan PADE sendiri diambil langsung dari APBD Kabupaten Lamongan Tahun Anggaran 2013. Harga yang harus dibayarkan untuk membeli PADE sebesar 20 juta rupiah untuk aplikasi yang diambilkan dari APBD 2013. Beberapa desa di Kabupaten Lamongan yang sebelumnya memiliki Abinduk pengadaannya swadaya dari desa. Pengadaan Abinduk sendiri diambil dari Alokasi Dana Desa (ADD) seharga 400 ribu rupiah dengan tambahan 200 ribu untuk input data penduduk.

Tujuan dari penerapan IT untuk layanan administrasi publik, dengan mengusulkan beberapa layanan online adalah untuk (a) meningkatkan operasinya, (b) untuk membuat prosedur administrasi yang mudah dan (c) untuk meminimalkan biaya dan waktu pengiriman pelayanan publik (West, 2004).

Usaha penyelarasan operasional menilai tingkat pendanaan dan sejauhmana komitmen sumber daya manusia dan keuangan selaras dengan strategi $e$-Government. Proses Kegiatan adalah dengan mempertimbangkan sebagai berikut:

1) Dana atau anggaran tertentu telah tersedia untuk implementasi Strategi e-Government.

2) Rencana strategis investasi inisiatif $e$ Government untuk masa depan.

3) Realokasi anggaran untuk pembiayaan inisiatif e-Government.

4) Model yang diterapkan atau digunakan untuk mengukur kebutuhan keuangan dalam pembiayaan inisiatif e-Government.

5) Analisis survei biaya manfaat dan kepuasan pelanggan telah dilakukan untuk menentukan dampak pada biaya pelayanan.
Dalam aspek penganggaran, tiap daerah masih mengalami kendala dalam besaran anggaran yang diperlukan untuk membangun sistem, namun masih di beberapa daerah sudah ada rencana untuk realisasi anggaran dalam pelaksanaan layanan yang berbasis IT. Kabupaten Lamongan sudah mempunyai regulasi yang mengatur, sehingga untuk penganggaran dapat sedikit teratasi, selain itu di Kabupaten Lamongan sudah memiliki KPDE yang berwenang untuk pengembangan PADE bersama bagian Pemdes. Solusi untuk penyelesaian masalah kelembagaan tersebut adalah dapat diawali dengan pembuatan lembaga yang berwenang untuk pengembangan IT dengan payung regulasi yang jelas.

\section{Pelayanan IT}

Layanan yang dibutuhkan oleh masyarakat sangat beragam. Untuk jenis dan urusan layanan yang diberikan di semua desa/kelurahan sama. Dengan kemajuan teknologi, harapannya dapat diterapkan untuk layanan di desa/kelurahan. Kebutuhan akan layanan masyarakat yang ada di desa adalah terkait dengan layanan administrasi kependudukan, diantaranya:

- KTP (Kartu Tanda Penduduk);

- KK (Kartu Keluarga);

- SKTM (Surat Keterangan Tidak Mampu);

- Surat Keterangan Usaha;

- Surat Waris;

- Surat Keterangan Pindah;

- Surat Keterangan Domisili;

- SKCK (Surat Keterangan Cacat Kriminal);

- Dan surat-surat lainnya.

Kabupaten Lamongan untuk menunjang layanan telah dibuat kebijakan pembuatan sistem aplikasi IT untuk administrasi desa. Aplikasi khusus pelayanan yaitu Pengolahan Administrasi Desa Secara Elektronik (PADE). Sesuai dengan regulasi yang ada, PADE akan digunakan untuk layanan kependudukan, pertanahan, keuangan, dan surat-menyurat, namun pada penerapannya PADE terbatas pada layanan surat-menyurat dan kependudukan. Layanan surat-menyurat digunakan untuk mengakomodasi layanan terkait administrasi kependudukan, sedangkan layanan kependudukan digunakan dengan pembuatan database penduduk. Dari 4 sampel desa yang diambil dalam 2 kecamatan yang 
menggunakan PADE, ada 1 desa yang belum menggunakan PADE yang diberikan oleh Pemkab Lamongan. Sebelum ada PADE, sudah ada beberapa desa yang menggunakan aplikasi Administrasi Berbasis Nomor Induk Penduduk (Abinduk) untuk pelayanan. Abinduk ini fungsinya sama seperti PADE yang diberikan oleh Pemkab. Kedua program tersebut masingmasing memiliki kelebihan dan kelemahan, kelebihan PADE adalah dapat dimasukkan foto warga, sedangkan Abinduk tidak bisa. Kelebihan Abinduk sendiri adalah bisa digunakan untuk memberi ruang khusus yang dapat mewadahi kemauan desa, misalnya di Desa Putatkumpul yang digunakan untuk pembayaran rekening air. Aplikasi lain yang ada di pelayanan administrasi desa adalah Profil Desa dan Kelurahan (PRODESKEL), yang merupakan aplikasi online yang diberikan oleh Kementrian Dalam Negeri terkait pengisian profil desa. PRODESKEL memberikan akses pada desa untuk mengisi profil secara online. Didalam kelancaran penyelenggaraan program PADE, dibentuk tim pelaksana yang ditetapkan oleh regulasi yang ada, dengan anggota tim pelaksana dari bagian Pemdes dan KPDE. Tim pelaksana bertugas untuk melakukan pengendalian dan evaluasi pelaksanaan program PADE dan melaporkan hasil pelaksanaan tugas dan tanggung jawabnya kepada kepala daerah. Program PADE masih dilaksanakan di desa percontohan, diharapkan nantinya untuk dapat menjadi acuan penyelenggaraan program PADE. Dalam melaksanakan program PADE, masing-masing desa menunjuk sekretaris desa dan/atau perangkat desa lainnya sebagai operator program dengan syarat harus benar-benar menguasai dasar-dasar pengoperasian komputer.

Jadi, dari penjelasan di atas dapat disimpulkan bahwa penerapan dan pengembangan IT dalam aspek pelayanan masih belum maksimal dan belum merata di semua desa. Penerapan IT kedepannya harus dapat mengakomodir semua kebutuhan layanan dengan pembuatan sistem yang lebih baik dengan mengembangan sistem yang sudah ada dan diterapkan di semua desa.

\section{KESIMPULAN DAN SARAN Kesimpulan}

1. Kesiapan penerapan TIK dilihat dari aspek sumberdaya manusia, sarana prasarana, kelembagaan dan anggaran.

a. Ketersediaan SDM yang mampu mengoperasikan TIK di tingkat desa masih sangat terbatas.

b. Sarana prasarana terkait TIK masih dalam hal pemenuhan perangkat komputer baik software maupun hardware, namun ketersediaan jaringan komputer masih terbatas di beberapa daerah.

c. Kelembagaan yang ada sudah mencukupi untuk penerapan dan pengembangan TIK lebih lanjut.

d. Kebutuhan anggaran dapat terpenuh karena adanya lembaga yakni KPDE dan didukung Bagian Pemerintahan Desa yang mempunyai kewenangan sehingga dapat dimasukkan dalam mata anggaran pembangunan.

2. Penerapan dan pengembangan IT dalam aspek pelayanan masih belum maksimal dan belum merata di semua desa dan belum mengakomodir semua kebutuhan layanan masyarakat.

\section{Rekomendasi dan Saran}

1. Meningkatkan jumlah SDM yang mampu mengoperasikan TIK di tingkat desa. Pelatihan-pelatihan peningkatakan kapasitas terkait IT tidak hanya untuk operator, karena di masa mendatang pelayanan administrasi akan sangat banyak melibatkan IT. Terbatasnya SDM yang menguasai TIK akan menimbulkan permasalahan layanan apabila yang bersangkutan berhalangan masuk kantor sehingga pelayanan menjadi terhambat.

2. Pemerintah Pusat, Propinsi dan Kabupaten/Kota harus sudah mulai beraksi dalam menghubungkan semua tempat di Indonesia melalui jaringan internet, tidak hanya bersandar pada cakupan jaringan melalui BTS (base transceiver station) yang sering terkendala dengan cuaca tapi juga mempercepat pembangunan jaringan serat optik. TIK sangat tergantung dengan jaringan yang memadai karena apabila TIK tidak ditunjang dengan jaringan maka kinerja TIK hanya mengakses data lokal. Keterkaitan data yang menjadi keutamaan TIK menjadi hilang apabila tidak ditunjang oleh jaringan karena menyebabkan data yang ada di pusat server tidak terupdate pada saat yang sama.

3. Anggaran Pemerintah selalu terbatas dan 
dibatasi oleh program prioritas sehingga tidak bisa melakukan penganggaran sekaligus dalam satu tahun anggaran. Pengadaan sistem dan segala kebutuhan terkait TIK perlu dianggarkan setiap tahun agar dapat memenuhi kebutuhan di setiap desa.

4. Penerapan dan pengembangan IT merupakan satu proses dimana sistem yang dibangun tidak bisa langsung sempurna tetapi di bangun secara bertahap dan diperbaiki agar memenuhi harapan pelayanan. Sistem yang sekarang dapat menjadi dasar untuk pengembangan sesuai dengan perubahan peraturan dari peraturan yang lama menjadi baru yakni undangundang tentang Desa. Saat ini, peraturan pelaksanaan terkait sistem informasi masih menunggu peraturan dari kementerian terkait.

\section{DAFTAR PUSTAKA}

ADB (2011).e-Goverment Capability Maturity Model: Improving Public Services through Information and Communication Technology. diunduh dari http://www.unapcict.org/ecohub/eGovernment-capability-maturity-model diakses Kamis, 07 Februari 2013.

Al-Khouri, A. M. (2011) An Innovative Approach For E-Government Transformation. diunduh dari http://arxiv.org/ftp/arxiv/papers/1105/11 05.6358.pdf. diakses Jumat, 01 Februari 2013.

Charalabidis Y., Gionis G., Lampathaki F., Askounis D., Metaksiotis K. (2006), Organising Municipal e-Government Systems: A Multi-Facet Taxonomy of eServices for Citizens and Businesses, DEXA eGov Conference 2006, Krakow, Poland.

Depdagri (2007). Naskah Akademik Tentang Rancangan Undang-Undang Tentang Desa. Direktorat Pemerintahan Desa Dan Kelurahan, Direktorat Jenderal Pemberdayaan Masyarakat Dan Desa, Departemen Dalam Negeri, Jakarta.

Gil-Garcia, J. R. and T. A. Pardo, 2005. Egovernment success factors: Mapping practical tools to theoretical foundations. Gov. Inform. Quart. , 22: 187-216.

Heeks, Richard. 2001a. Building e-Governance for Development: A Framework for National and Donor Action. $i$ -
Government Working Paper Series, Paper No. 12, Institute for Development Policy and Management, University of Manchester, Manchester, UK (http://www.man.ac.uk /idpm/idpm_dp.htm\#ig).

Heeks, Richard. 2001b. Understanding $e$ Governance for Development. $i$ Government Working Paper Series, Paper No. 11, Institute for Development Policy and Management, University of Manchester, Manchester, UK (http://www.man.ac.uk/idpm/idpm_dp.h tm\#ig).

keputusan Bupati Lamongan No. 188/324/Kep/413.013/2013 tentang Penunjukan Desa Percontohan Pelaksanaan Program Pengolahan Administrasi Desa Secara Elektronik (PADE)

Keputusan Menteri Pendayagunaan Aparatus Negara nomor: 63/KEP/M.PAN/7/2003 tentang Pedoman Umum Penyelengaraan Pelayanan Publik.

Lulita, M. C. (2011). Kinerja birokrasi desa dalam meningkatkan pelayanan umum di Desa Cukurgondang Kecamatan Grati Kabupaten Pasuruan. diunduh dari http://library.um.ac.id/freecontents/index.php/ pub/ detail/kinerjabirokrasi-desa-dalam-meningkatkanpelayanan-umum-di-desacukurgondang-kecamatan-gratikabupaten-pasuruan-mega-clara-lulita48942.html diakses Rabu, 06 Februari 2013.

McNabb, David E. 2010. Research methods for political science. Quantitative and qualitative approaches. 2nd ed. Armonk, N.Y: M.E. Sharpe.

Peraturan Menteri Dalam Negeri Nomor 62 Tahun 2008

Peraturan Pemerintah Republik Indonesia Nomor 72 Tahun 2005 Tentang Desa

The Department of Human Services (2011). Service Delivery Reform: Transforming government service delivery. diunduh dari http://www.humanservices. gov.au/spw/corporate/aboutus/resources/service-delivery-reformoverview. pdf diakses Selasa, 05 Februari 2013 jam 07:58. 
UU nomor 6 tahun 2014 tentang Desa

Vintar, M, M Kunstelj, A Leben - 2002. Delivering better quality public services through life-event portals. 10th NISPAcce Annual Conference, 2002

West, D. (2004). E-Government and The Transformation of Service Delivery and
Citizen Attitudes. Public Administration Review, 64(1): 15-27.

Wikidepia (2013). E-Governance. From Wikipedia, the free encyclopedia diunduh dari http://en.wikipedia.org/wiki/E-

Governance diakses Jumat, 01 Februari 2013. 